\title{
A study on the influence of poultry feed on the size, weight and protein content of egg
}

\author{
Revathy. S
}

Assistant Professor, Department of Zoology, St Xavier’s College for Women, Aluva- 683101, Kerala, India

Corresponding author: Revathy. $\mid$ | Email: revathy@stxaviersaluva.ac.in

Received: 12-10-2020, Accepted: 16-11-2020, Published online: 20-12-2020

\begin{abstract}
The egg of domestic fowl has been an important constituent of the cuisine of people around the world. The present study was carried out with the objective to analyse the influence of selected poultry feed on the size, weight and protein content of egg by feeding the hens with four different types of feed. Hens of the laying Gramasree variety were used in this experiments. Egg size, weight and the protein content was recorded as per standard procedures. Egg production significantly reduced in hen fed with cooked rice alone. When considering egg size and weight, domestic fowl fed with wheat, soya and groundnut had greater size. However, there has not been much variation in the protein content of all the eggs produced by the four hens in the present study. The study provides a baseline indication that the quality, size and weight of the egg are greatly influenced by their feed.
\end{abstract}

Keywords: Poultry feed, laying fowl, egg protein, egg quality

\footnotetext{
doi: https://doi.org/10.51128/jfas.2020.A022 | How to cite this article: Revathy. S. 2020. A study on the influence of poultry feed on the size, weight and protein content of egg. Journal of Food and Animal Sciences, 01(02): 121-125.

Copyright: Revathy, 2020. Open Access. This article is distributed under the terms of the Creative Commons Attribution 4.0 International License (http://creativecommons.org/licenses/by/4.0/), which permits unrestricted use, distribution, and reproduction in any medium, provided you give appropriate credit to the original author(s) and the source, provide a link to the Creative Commons license, and indicate if changes were made. The Creative Commons Public Domain Dedication waiver (http://creativecommons.org/publicdomain/zero/1.0/) applies to the data made available in this article, unless otherwise stated.
} 


\section{Introduction}

The egg of domestic fowl is an integral part of diet for non-vegetarians and eggetarians. It is a valued food source for convalescents and invalids. It is very important to learn in how and to what extent; the feed consumed by hens affect the composition and dietetic value of the eggs they produce. A hen's daily consumption of feed depends on the composition of feed. Feed ingredients for poultry diets are selected for the nutrients they can provide. Feed formulation helps to derive a balanced diet there-by ensuring the bioavailability of nutrients required by the bird. In addition to energy and protein, the formulations also provide minerals, vitamins and specific amino acids supplements. These supplements ensure health and performance of the fowl to lay eggs. The present study was undertaken to analyse the influence of selected poultry feed on the size, weight and protein content of egg.

\section{Materials and Methods}

\section{Selecting the feed and hens}

Four hens belonging to the same breed has been selected for conducting the feeding experiment and are named as A, B, C, and D. Four types of poultry feed were selected for each hen as cooked rice for hen A, whole wheat grain for hen $B$, an economic poultry feed for hen $\mathrm{C}$ and a mixture of rice and powdered wheat, soya, peanut and sugar for hen D.

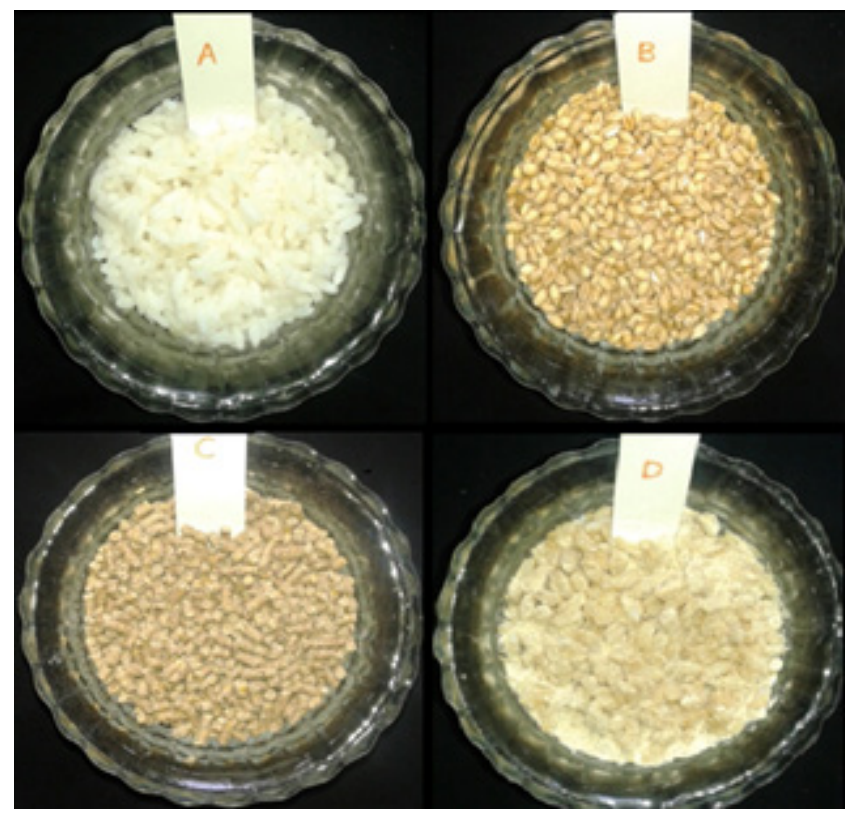

Figure 1. Different Types of Feed used in the study
The cage was divided into four sections for each hen. The selected feed and water has been supplied inside the cages. The Feeding experiment was continued uninterrupted for a period of three months. After three months, the egg size, weight and the protein content in egg samples were analyzed.

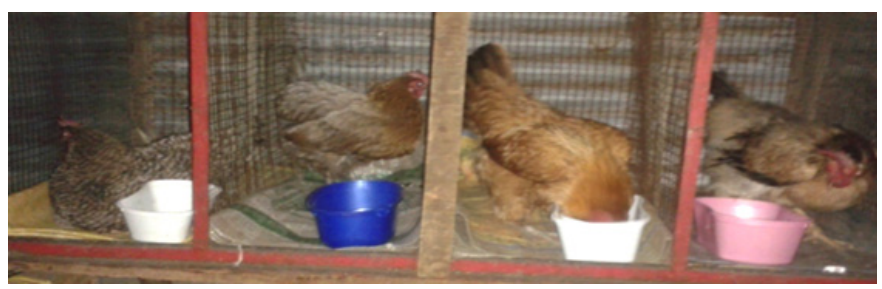

Figure 2. Hen used for the study

\section{Egg Size and Weight Measurement}

Size and weight of the eggs were measured. The length and maximum breadth of each egg was measured using vernier caliper to know its size. An accurate measurement of weight was done using digital weighing balance.
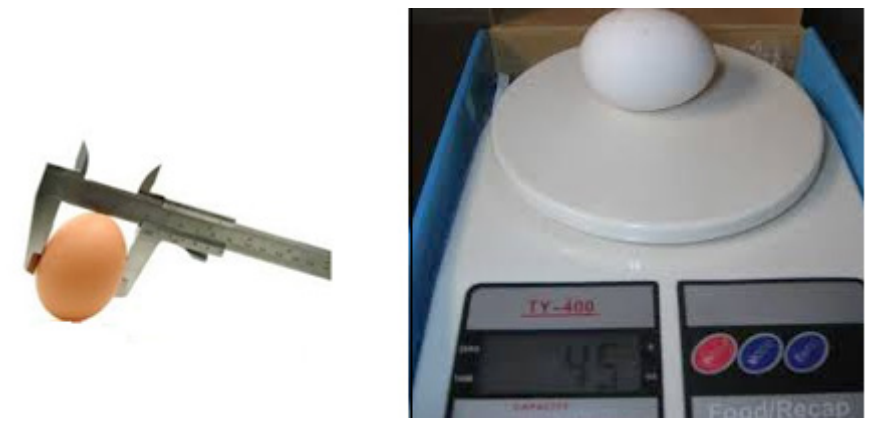

Figure 3. Egg size and Weight Measurement

\section{Determination of Protein in Egg}

The liquid whole egg (2-2.2 gm) was digested using Micro- Kjeldahl digester in presence of digestion mixture which acts as catalyst (sodium sulfate/potassium sulfate: copper sulfate $=5: 1$ ) and $40 \mathrm{ml}$ sulfuric acid. Flask was placed in an inclined position and heated gently until frothing ceases, then boiled rapidly until solution became clear. The sample was then cooled and distilled water was added to make the volume upto $250 \mathrm{ml}$. The diluted sample $(10 \mathrm{ml})$ was distilled with $10 \mathrm{ml}$ of $40 \% \mathrm{NaOH}$ using MicroKjeldahl distillation unit. Steam was distilled over 2\% boric acid $(25 \mathrm{ml})$ containing mixed indicator (1 part $0.2 \%$ methyl red +2 part $0.2 \%$ bromocresol green dye) 
for $30 \mathrm{~min}$. The ammonia trapped in boric acid was determined by titrating with $0.1 \mathrm{~N}$ sulfuric acid. The nitrogen percentage was calculated using the following formula:

$$
(\mathrm{A}-\mathrm{B}) \times 0.0014 \times
$$

Total volume made
Nitrogen $(\%)=---$ Weight of sample taken $\times 100$ Volume of distillate

Where, $A=$ Titrated value for sample

$\mathrm{B}=$ Titrated value for blank

Protein percentage was determined by conversion of nitrogen percentage to protein by using conversion factor (5.73) as per Sosulski and Imafidon, 1990.

\section{Results and Discussion}

\section{Egg Size}

From the four sets A, B, C and D, 10 eggs for each category were collected. Length and breadth was recorded in $\mathrm{cm}$. Category D had greater size (Length $4.6 \pm 0.043 \&$ Breadth $4.1 \pm 0.054)$ followed by A (Length $4.4 \pm 0.047 \&$ Breadth $3.8 \pm 0.066$ ). The eggs in category C (Length $4.3 \pm 0.049$ \& Breadth $3.8 \pm 0.068$ ) had intermediate size while Category B (Length $4.00 \pm$ $0.065 \&$ Breadth $3.7 \pm 0.077)$ had the lowest size. The eggs also showed slight variation in their shapes (Fig. 4 and 5).

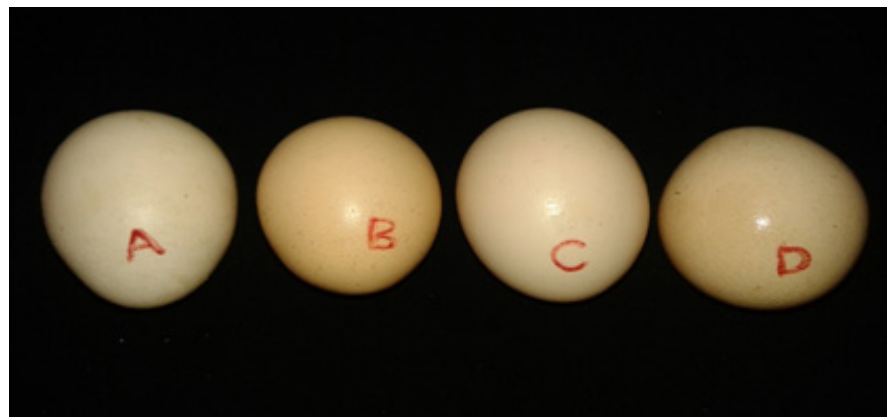

Figure 4. Eggs collected after three months of feeding experiment

\section{Egg Weight}

The egg in category $\mathrm{D}$ that is laid by the hen fed with a mixture of rice and powdered wheat, soya, peanut and sugar had the highest weight $(55 \pm 0.043$ gm). The egg in category B, laid by the hen fed with whole-wheat grain alone had the lowest weight $44 \pm$
$0.11 \mathrm{gm})$. The eggs in categories $\mathrm{A}$ and $\mathrm{C}$ possessed intermediate weights; (52 $\pm 0.15 \mathrm{gm}, 50 \pm 0.047 \mathrm{gm})$ respectively.

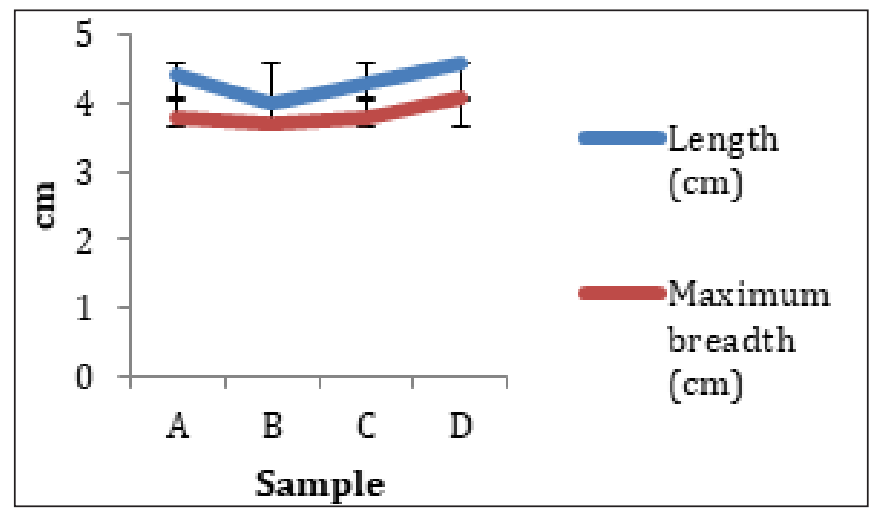

Figure 5. Variation in size of Eggs

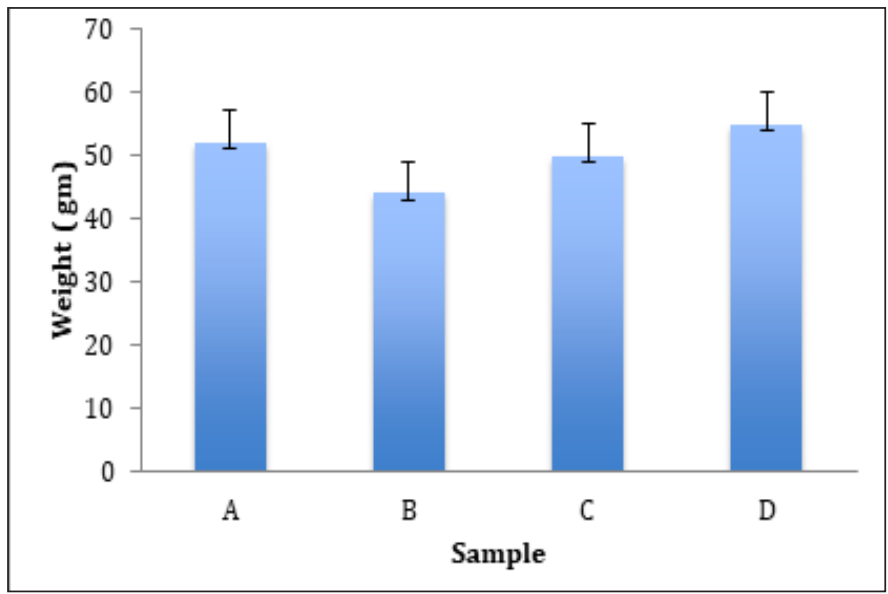

Figure 6. Variation in weight of Eggs

\section{Protein content}

Slight variation in protein content was noted for the egg laid by the four sets fed with different feeds. It was observed that eggs from sample D laid by hen fed with wheat and a mixture of cooked rice and powdered wheat, soya, peanut, and sugar respectively had highest protein content, $13 \pm 0.043 \%$. The lowest protein content has been observed in egg A (11.1 \pm $0.047 \%$ ) laid by the hen fed with cooked rice. The eggs $\mathrm{C}$ that was laid by the hen fed with economic poultry feed had intermediate protein content of $12.5 \pm 0.049$ $\%$ and the eggs $B$ that was laid by the hen fed wholewheat grain had $12.5 \pm 0.065 \%$.

Over the years, the composition of laying hen diets has gone through many changes. This is because the diet fed to commercial laying hens can vary depending on factors such as the strain of 
layer, production goals, age, and weather conditions (Schaible and Patrick, 1980). A laying hen depends on the nutrients provided through diet to produce eggs, the quality and formulation of the diet is most important to a producer, especially considering that 65 to $75 \%$ of the cost to produce eggs is due to feed costs (Bell and Weaver, 2002). It has become increasingly important for producers to find a balance between feeding their birds on a least-cost basis and feeding the appropriate amounts of nutrients in the diet, as the hen needs them throughout her lay cycle to maximize profits.

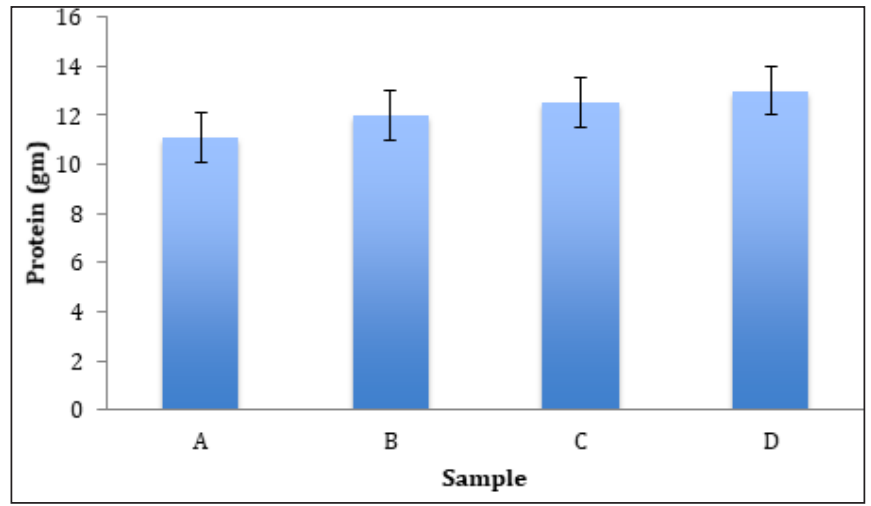

Figure 7. Protein content in Eggs

There has been a significant reduction in egg production in hen A when cooked rice alone was fed. This may be due to problems of amino acid deficiency, imbalance in feed. Similar results due to lack of amino acids were observed by Grau and Almquist (1944) and (Hill 1969).

It is well known that egg size usually increases as dietary protein increases; however, the protein intake needed to achieve maximum egg size is unclear. In our study also, the egg size of hen $\mathrm{D}$ was higher which was fed with wheat, soya and groundnut. Leeson (1989) reported that egg size was dramatically increased as daily protein intake increased.

Numerous investigations have focused on methods of influencing egg weight through diet manipulation during various production phases. In the present study, egg produced by hen $\mathrm{D}$ had greater weight also. Increasing levels of protein might have resulted in improved egg size and weight (Leeson, 1989; Pesti, 1991; Parsons et al., 1993; Keshavarz and Nakajima, 1995). Parsons et al., (1993) reported that there was a substantial effect on egg weight and size grade out by increasing dietary CP from 16 to $18 \%$.

There has not been any considerable variation in the protein content of all the eggs produced by the four hens in the present study. The value of protein content was between 11.10-13\%. It has been observed by Larbier et al. 1994, that reduced crude protein level inclusion in the diet will not affect egg qualities but will only reduce the level of egg production of the laying bird.18-19 grams of protein/bird/ day is needed for large egg production. Decreasing protein level by too much will decrease egg numbers as well.

\section{Conclusion}

The present study provides a baseline indication that the quality, size and weight of the egg are greatly influenced by their feed. The effect of diet ingredients and their composition including starch, protein, sugar, fat, fiber results in variation in the quality, size and weight of eggs. The quality and formulation of poultry feed is most important in determining the egg quality and size. Therefore, the quality and formulation of the diet must be dealt with utmost importance as a laying hen draws on the nutrients provided in its diet to produce eggs.

\section{Authorship contribution statement}

Revathy. S : Conceptualization, Writing - original draft, Writing - review \& editing,

\section{Acknowledgments}

The author wishes to acknowledge the Department of Zoology, St Xavier's College for Women, Aluva for the necessary support.

\section{Funding}

This research received no specific grant from any funding agency in the public, commercial, or not-forprofit sectors.

\section{Declaration of Competing Interest}

All authors declare that there exist no commercial or financial relationships that could, in any way, lead to a potential conflict of interest.

\section{References}

Bell, D. D. and Weaver, W. D. 2002. Commercial chicken meat and egg production. $5^{\text {th }}$ Edn. Kulwer academic Publisher, Norwell, M A.

Grau, C. R. and Almquist, H. J. 1944. Beef blood proteins in chick diets. Poultry Science 23:486- 
490.

Hill, F. W. 1969. Poultry nutrition and nutrient requirements In: Cuthbertson, O. International Encyclopaedia of Food and Nutrition. $2^{\text {nd }}$ Edn. Pergamon Press London.

Keshavarz, K. Nad Nakajima, S. 1995. The effect of dietary manipulations of energy, proteins and fat during the growing and laying periods on early egg weight and egg components. Poultry Science. 74: 50-61.

Leeson, S. and Summers. J. D. 2005. Commercial Poultry Nutrition. $3^{\text {rd }}$ Edn. Nottingham University Press, Nottingham, UK.

Larbier, M. and Leclercq, B. 1994. Nutrition and Feeding of Poultry. Nottingham University
Press, Loughborough, p. 305.

Parsons, C. M, Koelkebeck, K. W., Zhang, Y. and Leeper R. W. 1933. Effect of dietary protein and added fat levels on performance of young laying hens. J. Appl. Poultry. Res. 2: 214-220.

Pesti, G. M, 1991. Response surface approach to studying the protein and energy requirements of laying hens. Poultry Science. 70: 103-114.

Schaible P. T and Patrick. H, 1980. Poultry: Feed and Nutrition. $2^{\text {nd }}$ Edn. AVI Publishing Company, Inc., Westport, C. T.

Sosulski, F. W. and Imafidon, G.I.1990. Amino acid composition and nitrogen-to-protein conversion factors for a nimal and plant foods. Agric. Food Chem. 38:1351- 1356. 